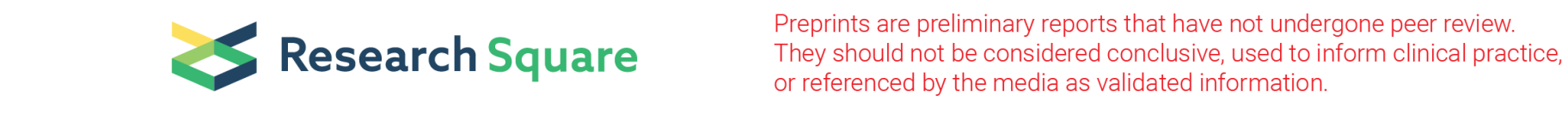

\title{
Evaluation of Mental Health Status of the Pregnant Women Working in Hospitals During Covid-19 Era
}

\author{
Mahboubeh Eslamzadeh \\ Mashhad University of Medical Sciences \\ Bita Najjari \\ Mashhad University of Medical Sciences \\ Maryam Emadzadeh \\ Mashhad University of Medical Sciences \\ Zhaleh Feyzi \\ Mashhad University of Medical Sciences \\ Farzaneh Modaresi \\ Fasa University of Medical Science
}

\section{Sara Mirzaeian}

Mashhad University of Medical Sciences

Aazam Sadat Heydari Yazdi ( $\sim$ heydariazm@gmail.com )

Mashhad University of Medical Sciences https://orcid.org/0000-0002-2222-1758

\section{Research}

Keywords: COVID-19, Anxiety, Pregnancy, Health care workers

Posted Date: November 9th, 2021

DOI: https://doi.org/10.21203/rs.3.rs-1039066/v1

License: (c) (i) This work is licensed under a Creative Commons Attribution 4.0 International License. Read Full License 


\section{Abstract}

\section{Background}

Women represent the majority of the healthcare workforce and many of these women are probably pregnant and working at the front-line during COVID-19 outbreak. In COVID-19 crisis healthcare workers experienced excessive issues and challenges that made them vulnerable for getting various mental health disorders. We aimed to evaluate the mental health state among pregnant health care workers in COVID-19 era.

\section{Methods}

This cross-sectional study included 64 pregnant clinical residents, general physicians, nurses and other medical staff who worked in the hospitals in Iran, from August 2020 to December 2020 using an anonymous online survey available on Google Form platform. The online survey consisted of socio demographic questions, pregnancy-related questions, and some questions about medical/drug history, The Persian versions of General Health Questionnaire - 28 (GHQ-28), and Corona Disease Anxiety Scale (CDAS) were also fulfilled by the participants.

\section{Results}

The mean age and gestational age of participants were $31.3 \pm 3.9$ years, and $24.5 \pm 10.1$ weeks. Psychological problems were moderate (total score GHQ-28> 40) in 9.4\% ( $: 6$ ) of the pregnant health care workers (PHCW). The frequency of moderate/severe problems in the four subclasses, including somatic symptoms, anxiety/insomnia, social dysfunction, and depression were 9(14.1\%), 25(39.0\%), 7(10.9\%), and 10(15.6\%), respectively. According to CDAS, $26.5 \%$ of participants had moderate to severe COVID-19 related anxiety. COVID-19 related anxiety and its subclasses, physical and psychological, were significantly correlated with GHQ-28 total score and its subclasses, including somatic symptoms, anxiety/insomnia, social dysfunction, and depression among pregnant health care workers $(P<0.01)$.

\section{Conclusion}

According to the results of the current study, over $25 \%$ of the pregnant health care workers have moderate to severe COVID- 19 related anxiety; so it is crucial for policymakers to focus on the mental health of the pregnant health care workers during COVID19 pandemic. This study has major implications on health care practice. Further studies are needed to draw a clear picture of mental health problems among PHCW.

\section{Background}

In late 2019, Chinese authorities announced an outbreak of rapid spreading viral pneumonia, later identified as a new Betacoronavirus named Severe Acute Respiratory Syndrome Coronavirus 2 (SARS-CoV-2). The novel coronavirus, SARS-CoV-2causing Corona- virus Disease 19 (COVID-19), emerged as an unprecedented public health threat in December 2019 and was declared a pandemic by the World Health Organization in March 2020 (1).

There is a large body of evidence that addressed the increased prevalence of psychiatric disorders and mental health issues such as dementia, perceived psychological stress, anxiety, and depression during the COVID-19 pandemic and similar outbreaks (2-4). In a national-wide survey in China, it is reported that national lockdown measures triggered a wide variety of psychological problems, such as panic disorder, anxiety, and depression in normal people as well as those with the previous mental health problems $(5,6)$.

In COVID-19 crisis, with the outrages hospitals overload and the shortage of facilities, healthcare workers experienced excessive workload, longer working hours, more night shifts, and perhaps physical or emotional violence (7-9). These catastrophic occupational stressors make them at most risk of getting various mental health issues, such as depression, anxiety, and sleep disorders $(10,11)$. 
Women comprise over $70 \%$ of the health care workface, and many of them, perhaps thousands, are pregnant at any given moment (12). Of note, many of these pregnant women are front-line health care workers in the COVID-19 era and are worried about the possible impacts of COVID-19 on their fetus (13). Although it is argued that pregnant women are not at an elevated risk for COVID-19 infections (14), pregnant health care workers seem to be at higher risk for anxiety, occupational stress, and depression. Besides, individuals with pre-existing mental issues, including bipolar disorder, substance use disorder, obsessivecompulsive disorder, depression, or anxiety, are more vulnerable to infection $(5,6,15)$. Based on the reasons presented above, it is crucial to study on mental health issues among pregnant health care workers. Furthermore, there is a lack of studies that investigate the mental health status of pregnant health care workers in the COVID-19 pandemic. Therefore, we conducted an online survey among pregnant health care workers, who work in referral hospitals of Iran, to better understand their mental state in COVID-19 crisis. Additionally, we evaluate the correlation between mental health status and the level of COVID-19 related anxiety in pregnant healthcare workers, including physicians, nurses, clinical staff, and medical trainees.

\section{Materials And Methods Study Design and Population}

This cross-sectional, observational study was carried out among 64 pregnant clinical residents, general physicians, nurses and other medical staff who worked in the tertiary referral hospitals in Iran, from August 2020 to December 2020 using an anonymous online survey available on Google Form platform. The study included the pregnant clinical personnel who were willing to fill the online survey completely and working at hospitals at the time of study. We exclude individuals with prior history of psychiatric disorders or those who used psychiatric medications. Pregnant clinical personnel recruited via social media professional groups/pages, including Telegram, WhatsApp, and Instagram. The survey link was also shared with specific medical communities to reshare through their networks of pregnant physicians.

This study was approved by the ethics committee of the Mashhad University of Medical Sciences (Ethics code: IR.MUMS.REC.1399.208). Each participant was free to decline to participate in this study with no consideration.

\section{Data Collection}

The online survey comprised of three sections: the first section consisted of sociodemographic questions, occupational questions, pregnancy-related questions, and questions about medical/drug history, the second section included the Persian version of General Health Questionnaire - 28 (GHQ-28), and the third section contained Corona Disease Anxiety Scale (CDAS).

\section{General Health Questionnaire - 28 (GHQ-28)}

The GHQ-28 was used to identify those who are at risk of developing psychiatric disorders.

GHQ-28 is a 28-item tool that assess the common mental health problems in four subscales, including somatic symptoms (items 1-7), anxiety/insomnia (items 8-14), social dysfunctions (items 15-21), and severe depression (items 22-28) (16). The items are answered on a Likert scale from zero to 3 . The maximum score is 84 , and a higher score present worsen mental health status. We used Persian version of GHQ-28 in the current study (17). Which its validity, and reliability were assessed by Nazifi et al. (17) and Cronbach's alpha was 0.923 .

\section{Corona disease anxiety scale (CDAS)}

Corona disease anxiety scale was used to evaluate corona-related anxiety in two domains, including psychological symptoms and physical symptoms, on a 4-point Likert scale from zero to 3 (never: 0, sometimes: 1, often: 2 and always: 3). The total score ranges between 0 and 54. We used Persian translated version of this questionnaire, with the reported Cronbach's alpha of 0.919 (18).

\section{Sample Size and Statistical Analyses}

According to the study conducted by Judy Ng et al. in 2013 (19), which about 65\% of pregnant women reported the moderate level of anxiety during SARS pandemic, the minimum sample size was calculated as 52 (considering $p=0.65, d=0.2 p$ and $a=$ 
0.05).

All statistical analyses were performed using the SPSS for Windows, version 22 software package (SPSS Inc., Chicago, IL, USA). Kolmogorov-Smirnov test was used to assess for normality of the quantitative variables. Data were expressed as means (SD) for parameters with a normal distribution or median (interquartile range) for non-normally distributed data.

A two-sided P value $<0.05$ was considered statistically significant. Bivariate correlations between different parameters and GHQ28 and CDAS score were performed using Pearson or Spearman's correlation test.

\section{Results}

\section{Demographics and Pregnancy-related Characteristics}

This study included 64 pregnant health care workers with the mean age of $31.3 \pm 3.9$ years. The demographic and clinical characteristics were summarized in Table 1 . The majority of subjects had $<5$ years work experiences $(65.6 \%$, $n$ : 42$)$. About onethird of pregnant health care workers ( $\mathrm{n}: 22)$ have thought about abandoning their profession within the past month of the study (Table 1).

The mean of gestational age of the participants was $24.5 \pm 10.1$ weeks. Table 2 illustrates that more than half of participants experienced their first pregnancy $(57.8 \%, \mathrm{n}: 37)$. Eleven subjects reported having one or more prior abortions (17.2\%). Similarly, the frequency of unintended current pregnancy was 11 (17.2\%) among pregnant health care workers (Table 2).

\section{Correlation between Mental Health Status and COVID-19 Related Anxiety with other Demographic, and Pregnancy-related Characteristics}

The mean score of GHQ-28 was $26.8 \pm 9.3$ and the median (Q1-Q3) of CDAS total score was 10.0 (6.0-16.7) (Table 3).

Psychological problems were moderate (total score GHQ-28> 40) in $9.4 \%(n: 6)$ of the pregnant health care workers. The frequency of moderate/severe problems in the four subclasses, including somatic symptoms, anxiety/insomnia, social dysfunction, and depression were 9 (14.1\%), 25 (39.0\%), 7 (10.9\%), and 10 (15.6\%), respectively. According to CDAS, $26.5 \%$ of participants had moderate to severe COVID-19 related anxiety. Besides, the frequency of moderate/severe physical and psychological subclasses of COVID-19 related anxiety were 29 (45.3\%), and 46 (71.9\%).

Pearson's correlation test showed that COVID-19 related anxiety and its subclasses, physical and psychological, were significantly correlated with GHQ-28 total score and its subclasses, including somatic symptoms, anxiety/insomnia, social dysfunction, and depression among pregnant health care workers $(P<0.01$, Table 4$)$. However, neither psychological distress (assessed by GHQ-28) nor COVID-19 related anxiety were correlated with demographic and pregnancy related characteristics (Table 4).

Table-1: Demographic and clinical characteristics of pregnant health care workers 


\begin{tabular}{|c|c|}
\hline Variable & $\begin{array}{l}\mathrm{n}: 64 \\
\mathrm{n}(\%)\end{array}$ \\
\hline Age $(y)^{*}$ & $31.3 \pm 3.9$ \\
\hline \multicolumn{2}{|l|}{ Education } \\
\hline Diploma & $6(9.4)$ \\
\hline Bachelor/master's degree & $33(51.6)$ \\
\hline Doctoral/Professional degree or higher & $25(39.1)$ \\
\hline \multicolumn{2}{|l|}{ Profession } \\
\hline General physician/Clinical resident & $24(37.5)$ \\
\hline Nurse & $23(35.9)$ \\
\hline Other medical staff & $17(26.6)$ \\
\hline \multicolumn{2}{|l|}{ Work Experience } \\
\hline$<5 y$ & $42(65.6)$ \\
\hline $5-10 y$ & $10(15.6)$ \\
\hline$>10 y$ & $12(18.8)$ \\
\hline Close contact with confirmed COVID-19 patients & $8(12.5)$ \\
\hline \multicolumn{2}{|c|}{ Direct contact time with COVID-19 patients (hours/day) } \\
\hline$<0.5$ & $18(28.1)$ \\
\hline $1-4$ & $24(37.5)$ \\
\hline$>4.0$ & $22(34.4)$ \\
\hline \multicolumn{2}{|c|}{ Have you ever thought about abandoning your profession within the past month? } \\
\hline Yes & $22(34.4)$ \\
\hline No & $42(65.6)$ \\
\hline \multicolumn{2}{|l|}{ Past medical history } \\
\hline Hypothyroidism & $7(10.9)$ \\
\hline Gastrointestinal disorders & $3(4.7)$ \\
\hline Diabetes/Hypertension & $1(1.6)$ \\
\hline
\end{tabular}

Table-2: Pregnancy-related features of pregnant health care workers 


\begin{tabular}{|c|c|}
\hline Variable & $\begin{array}{l}\mathrm{n}: 64 \\
\mathrm{n}(\%)\end{array}$ \\
\hline Gestational age (week)* & $24.5 \pm 10.1$ \\
\hline History of a prior labor & $27(42.2)$ \\
\hline Yes & $27(42.2)$ \\
\hline \multicolumn{2}{|l|}{ Number of children } \\
\hline 0 & $37(57.8)$ \\
\hline 1 & $20(31.2)$ \\
\hline 2 & $7(10.9)$ \\
\hline \multicolumn{2}{|l|}{ Number of previous pregnancies } \\
\hline 0 & $30(46.9)$ \\
\hline 1 & $22(34.4)$ \\
\hline $2-3$ & $10(15.6)$ \\
\hline History of abortion & $11(17.2)$ \\
\hline Gestational diabetes mellitus & $4(6.3)$ \\
\hline Gestational Hypertension & $3(4.7)$ \\
\hline History of Infertility & $4(6.3)$ \\
\hline Unintended Pregnancy & $11(17.2)$ \\
\hline \multicolumn{2}{|c|}{ *Data were expressed as mean \pm SD } \\
\hline
\end{tabular}

Table-3: General Health Questionnaire -28 and Corona Disease Anxiety Scale levels among pregnant health care workers

\begin{tabular}{|ll|}
\hline Variable & n: 64 \\
\hline General Health Questionnaire -28 total score & mean \pm SD \\
\hline Somatic symptoms (items 1-7) & $26.8 \pm 9.3$ \\
\hline Anxiety/insomnia (items 8-14) & $7.5 \pm 3.6$ \\
\hline Social dysfunction (items 15-21) & $9.6 \pm 5.4$ \\
\hline Severe depression (items 22-28) & $7.0 \pm 3.2$ \\
\hline Corona Disease Anxiety Scale total score* & $2.7 \pm 3.4$ \\
\hline CDAS psychological symptoms* & $10.0(6.0-16.7)$ \\
\hline CDAS physical symptoms* & $9.0(5.0-13.0)$ \\
\hline $\begin{array}{l}\text { *Data were expressed as mean } \pm \text { SD for normally distributed parameters or median (Q1-Q3) for non-normally distributed } \\
\text { parameters. }\end{array}$ & $1.0(0.0-4.0)$ \\
\hline
\end{tabular}

Table-4: Correlation between General Health Questionnaire -28 and Corona Disease Anxiety Scale scores with other demographic, and clinical and pregnancy-related characteristics 


\begin{tabular}{|c|c|c|c|c|c|c|c|c|}
\hline Variable & $\begin{array}{l}\text { GHQ-28 } \\
\text { total } \\
\text { score } \\
\text { r (p- } \\
\text { value) }\end{array}$ & $\begin{array}{l}\text { GHQ-28 } \\
\text { Somatic } \\
\text { symptoms } \\
\text { r (p-value) }\end{array}$ & $\begin{array}{l}\text { GHQ-28 } \\
\text { Anxiety/ } \\
\text { insomnia } \\
\text { r (p- } \\
\text { value) }\end{array}$ & $\begin{array}{l}\text { GHQ-28 } \\
\text { Social } \\
\text { dysfunction } \\
\text { r (p-value) }\end{array}$ & $\begin{array}{l}\text { GHQ-28 } \\
\text { Severe } \\
\text { depression } \\
r \text { (p-value) }\end{array}$ & $\begin{array}{l}\text { CDAS } \\
\text { total } \\
\text { score } \\
r \text { (p- } \\
\text { value) }\end{array}$ & $\begin{array}{l}\text { CDAS } \\
\text { physical } \\
\text { symptoms } \\
\text { r (p-value) }\end{array}$ & $\begin{array}{l}\text { CDAS } \\
\text { psychological } \\
\text { symptoms } \\
\text { r (p-value) }\end{array}$ \\
\hline Age (y) & $\begin{array}{l}-0.11 \\
(0.37) \star\end{array}$ & $\begin{array}{l}-0.05 \\
(0.72)\end{array}$ & $\begin{array}{l}-0.02 \\
(0.87)^{\star}\end{array}$ & $\begin{array}{l}-0.07 \\
(0.60) \star\end{array}$ & $\begin{array}{l}-0.09 \\
(0.50)\end{array}$ & $\begin{array}{l}-0.03 \\
(0.83)\end{array}$ & $\begin{array}{l}-0.03 \\
(0.85)\end{array}$ & $-0.03(0.83)$ \\
\hline $\begin{array}{l}\text { Gestational } \\
\text { age }\end{array}$ & $\begin{array}{l}-0.01 \\
(0.93)\end{array}$ & $\begin{array}{l}-0.14 \\
(0.27)\end{array}$ & $\begin{array}{l}0.04 \\
(0.77)\end{array}$ & $0.08(0.52)$ & $\begin{array}{l}-0.02 \\
(0.88)\end{array}$ & $\begin{array}{l}0.05 \\
(0.69)\end{array}$ & $\begin{array}{l}0.01 \\
(0.97)\end{array}$ & $0.09(0.50)$ \\
\hline $\begin{array}{l}\text { Number of } \\
\text { children }\end{array}$ & $\begin{array}{l}-0.18 \\
(0.16)\end{array}$ & $\begin{array}{l}-0.20 \\
(0.11)\end{array}$ & $\begin{array}{l}-0.15 \\
(0.25)\end{array}$ & $0.11(0.39)$ & $\begin{array}{l}-0.14 \\
(0.28)\end{array}$ & $\begin{array}{l}0.01 \\
(0.92)\end{array}$ & $\begin{array}{l}-0.02 \\
(0.88)\end{array}$ & $0.04(0.77)$ \\
\hline $\begin{array}{l}\text { Number of } \\
\text { previous } \\
\text { pregnancies }\end{array}$ & $\begin{array}{l}-0.19 \\
(0.13)\end{array}$ & $\begin{array}{l}-0.22 \\
(0.09)\end{array}$ & $\begin{array}{l}-0.14 \\
(0.26)\end{array}$ & $0.02(0.87)$ & $\begin{array}{l}-0.10 \\
(0.45)\end{array}$ & $\begin{array}{l}0.06 \\
(0.66)\end{array}$ & $\begin{array}{l}0.03 \\
(0.82)\end{array}$ & $0.07(0.57)$ \\
\hline $\begin{array}{l}\text { Level of } \\
\text { education }\end{array}$ & $\begin{array}{l}0.09 \\
(0.47)\end{array}$ & $\begin{array}{l}0.13 \\
(0.30)\end{array}$ & $\begin{array}{l}0.10 \\
(0.44)\end{array}$ & $-0.11(0.36)$ & $0.06(0.63)$ & $\begin{array}{l}-0.05 \\
(0.72)\end{array}$ & $\begin{array}{l}0.00 \\
(0.99)\end{array}$ & $-0.08(0.54)$ \\
\hline $\begin{array}{l}\text { Work } \\
\text { experiences } \\
\text { (y) }\end{array}$ & $\begin{array}{l}0.01 \\
(0.93)\end{array}$ & $\begin{array}{l}0.01 \\
(0.95)\end{array}$ & $\begin{array}{l}0.05 \\
(0.67)\end{array}$ & $-0.03(0.80)$ & $\begin{array}{l}-0.03 \\
(0.79)\end{array}$ & $\begin{array}{l}0.09 \\
(0.47)\end{array}$ & $\begin{array}{l}0.02 \\
(0.88)\end{array}$ & $0.14(0.26)$ \\
\hline $\begin{array}{l}\text { Direct contact } \\
\text { time with } \\
\text { COVID-19 } \\
\text { patients } \\
\text { (hours/day) }\end{array}$ & $\begin{array}{l}0.19 \\
(0.13)\end{array}$ & $\begin{array}{l}0.11 \\
(0.40)\end{array}$ & $\begin{array}{l}0.16 \\
(0.21)\end{array}$ & $0.09(0.48)$ & $0.08(0.55)$ & $\begin{array}{l}0.08 \\
(0.52)\end{array}$ & $\begin{array}{l}0.08 \\
(0.55)\end{array}$ & $0.08(0.54)$ \\
\hline $\begin{array}{l}\text { GHQ-28 total } \\
\text { score }\end{array}$ & - & $\begin{array}{l}0.82 \\
(<0.001)\end{array}$ & $\begin{array}{l}0.87 \\
(<0.001)\end{array}$ & $-0.24(0.06)$ & $\begin{array}{l}0.81 \\
(<0.001)\end{array}$ & $\begin{array}{l}0.61 \\
(<0.001)\end{array}$ & $\begin{array}{l}0.59 \\
(<0.001)\end{array}$ & $0.58(<0.001)$ \\
\hline $\begin{array}{l}\text { GHQ-28 } \\
\text { Somatic } \\
\text { symptoms }\end{array}$ & $\begin{array}{l}0.82 \\
(<0.001)\end{array}$ & - & $\begin{array}{l}0.67 \\
(<0.001)\end{array}$ & $-0.36(0.01)$ & $\begin{array}{l}0.46 \\
(<0.001)\end{array}$ & $\begin{array}{l}0.55 \\
(<0.001)\end{array}$ & $\begin{array}{l}0.52 \\
(<0.001)\end{array}$ & $0.52(<0.001)$ \\
\hline $\begin{array}{l}\text { GHQ-28 } \\
\text { Anxiety/ } \\
\text { insomnia }\end{array}$ & $\begin{array}{l}0.87 \\
(<0.001)\end{array}$ & $\begin{array}{l}0.67 \\
(<0.001)\end{array}$ & - & $\begin{array}{l}-0.51 \\
(<0.001)\end{array}$ & $\begin{array}{l}0.57 \\
(<0.001)\end{array}$ & $\begin{array}{l}0.67 \\
(<0.001)\end{array}$ & $\begin{array}{l}0.63 \\
(<0.001)\end{array}$ & $0.65(<0.001)$ \\
\hline $\begin{array}{l}\text { GHQ-28 } \\
\text { Social } \\
\text { dysfunction }\end{array}$ & $\begin{array}{l}-0.24 \\
(0.06)\end{array}$ & $\begin{array}{l}-0.36 \\
(0.01)\end{array}$ & $\begin{array}{l}-0.51 \\
(<0.001)\end{array}$ & - & $\begin{array}{l}-0.44 \\
(<0.001)\end{array}$ & $\begin{array}{l}-0.41 \\
(0.001)\end{array}$ & $\begin{array}{l}-0.34 \\
(0.01)\end{array}$ & $-0.44(<0.001)$ \\
\hline $\begin{array}{l}\text { GHQ-28 } \\
\text { Severe } \\
\text { depression }\end{array}$ & $\begin{array}{l}0.81 \\
(<0.001)\end{array}$ & $\begin{array}{l}0.46 \\
(<0.001)\end{array}$ & $\begin{array}{l}0.57 \\
(<0.001)\end{array}$ & $\begin{array}{l}-0.44 \\
(<0.001)\end{array}$ & - & $\begin{array}{l}0.43 \\
(<0.001)\end{array}$ & $\begin{array}{l}0.38 \\
(<0.001)\end{array}$ & $0.44(<0.001)$ \\
\hline $\begin{array}{l}\text { CDAS total } \\
\text { score }\end{array}$ & $\begin{array}{l}0.61 \\
(<0.001)\end{array}$ & $\begin{array}{l}0.55 \\
(<0.001)\end{array}$ & $\begin{array}{l}0.67 \\
(<0.001)\end{array}$ & $\begin{array}{l}-0.41 \\
(0.001)\end{array}$ & $\begin{array}{l}0.43 \\
(<0.001)\end{array}$ & - & $\begin{array}{l}0.94 \\
(<0.001)\end{array}$ & $0.96(<0.001)$ \\
\hline $\begin{array}{l}\text { CDAS } \\
\text { physical } \\
\text { symptoms }\end{array}$ & $\begin{array}{l}0.59 \\
(<0.001)\end{array}$ & $\begin{array}{l}0.52 \\
(<0.001)\end{array}$ & $\begin{array}{l}0.63 \\
(<0.001)\end{array}$ & $-0.34(0.01)$ & $\begin{array}{l}0.38 \\
(<0.001)\end{array}$ & $\begin{array}{l}0.94 \\
(<0.001)\end{array}$ & - & $0.81(<0.001)$ \\
\hline $\begin{array}{l}\text { CDAS } \\
\text { psychological } \\
\text { symptoms }\end{array}$ & $\begin{array}{l}0.58 \\
(<0.001)\end{array}$ & $\begin{array}{l}0.52 \\
(<0.001)\end{array}$ & $\begin{array}{l}0.65 \\
(<0.001)\end{array}$ & $\begin{array}{l}-0.44 \\
(<0.001)\end{array}$ & $\begin{array}{l}0.44 \\
(<0.001)\end{array}$ & $\begin{array}{l}0.96 \\
(<0.001)\end{array}$ & $\begin{array}{l}0.81 \\
(<0.001)\end{array}$ & - \\
\hline
\end{tabular}

\section{Discussion}


In this study, we sought to better understand the mental health issues and the COVID-19 related anxiety in pregnant health care workers in Iran. Besides, we assessed the correlation between mental health status using the GHQ-28 score and COVID-19 related anxiety. As we found, the prevalence of moderate to severe psychological problems and COVID-19 related anxiety among pregnant health care workers were $9.4 \%$ and $26.5 \%$, respectively. In addition, our results showed a significant correlation between COVID-19 related anxiety and its subclasses, physical and psychological, and GHQ-28 total score and its subclasses, including somatic symptoms, anxiety/insomnia, social dysfunction, and depression. Women comprise the majority of health care workers. Therefore, the high prevalence of mental health issues (both occupational and non-occupational) among health care workers and pregnant women would necessitate conducting a study about mental health issues of pregnant health care workers.

Pregnancy is known to be a phenomenon with various physiological and psychological changes, such as immune system alterations (20). Pregnant women are vulnerable to stress and mental health issues since they have many concerns about the effects of COVID-19 on their pregnancy and labor $(14,21)$. Although it is unclear whether pregnant women are at higher risk of developing severe COVID-19 and its complications, some studies suggested the probability of vertical transmission of COVID-19 to the fetus (22). In addition, some measures have been implemented that may increase the level of anxiety and psychological stress in pregnant women, including social distancing, minimizing in-person care, prohibiting labor partners for a time, and restricting visitors in postpartum wards (23-25).

According to the guidelines of several western countries, the employer is not allowed to continue employing a pregnant woman unless the risk of COVID-19 infection is equal to the general population. Besides, the pregnant health care workers should not have close physical contact with the COVID-19 patients and work with elective patients who were screened negative for COVID-19 $(26,27)$. However, in some countries, due to the COVID-19 crisis and the shortage of health care workers and facilities, pregnant health care workers have to work like their non-pregnant peers on the front lines of the fight against COVID-19 $(28,29)$. This disastrous circumstance would certainly affect their mental health status, as a result.

Sut et al. (30) reported that the prevalence of anxiety and depression was $64.5 \%$ and $56.3 \%$, among pregnant women during the COVID-19.

Liu et al showed that health care workers who had close physical contact with COVID-19 patients were more anxious and depressed compared with their counterparts who had no contact. Close contact with COVID-19 patients was also shown to negatively affect the medical staff's quality of life (31). In contrast, a recent study reported that there was higher prevalence of anxiety among non-medical healthcare workers without direct contact compared to medical personnel who might have direct contact with COVID-19 cases (32). It has been reported that the social support of health care workers was associated with selfefficacy and quality of sleep. However, it had an association with decreased levels of stress and anxiety (33). In the current study, COVID-19 related anxiety and its subclasses, physical and psychological, were significantly correlated with GHQ-28 total score and its subclasses, including somatic symptoms, anxiety/insomnia, social dysfunction, and depression among pregnant health care workers.

The present study has several limitations. One of the limitations is its cross-sectional design. The investigation of causal relationships is impossible with a cross-sectional design. Another limitation is that participation in the study was voluntary; thus, there was the possibility of selection bias. In addition, the in-person questionnaires seem to be more accurate and reliable than the on-line questionnaires. However, in order to minimize the physical contact, we selected the on-line questionnaires.

The prevalence of anxiety and mental health issues in pregnant health care workers is comparatively high in the COVID-19 era. Based on the results of the current study, it is crucial to pay more attention to the mental health of the pregnant health care workers during COVID-19 pandemic. Rapidly increasing the number of cases, shortage of facilities and medical staff, and not having information about the effects of COVID-19 on pregnancy and their fetus are the most crucial factors associated with the development of COVID-19 related anxiety and mental health problems in pregnant health care workers.

\section{Conclusions}


According to the results of the current study, over $25 \%$ of the pregnant health care workers have moderate to severe COVID- 19 related anxiety; so it is crucial for policymakers to focus on the mental health of the pregnant health care workers during COVID19 pandemic. This study has major implications on health care practice. Further studies are needed to draw a clear picture of mental health problems among PHCW.

\section{Abbreviations}

SARS-CoV-2: Severe Acute Respiratory Syndrome Coronavirus 2

COVID-19: Corona- virus Disease 19

GHQ-28: General Health Questionnaire - 28

CDAS: Corona Disease Anxiety Scale

PHCW: pregnant health care workers

\section{Declarations}

\section{Ethics approval and consent to participate:}

This study was approved by the ethics committee of the Mashhad University of Medical Sciences (Ethics code:

IR.MUMS.REC.1399.208). Each participant was free to decline to participate in this study with no consideration.

\section{Consent for publication:}

This manuscript doesn't contain any individual person's data.

\section{Availability of data and materials:}

The datasets during and/or analyzed during the current study available from the corresponding author on reasonable request.

\section{Competing interests:}

There is no conflict of interest.

\section{Funding:}

Mashhad University of Medical Sciences, Mashhad, Iran

\section{Authors' contributions:}

MEs and ZF proposed and designed this research. MEm analyzed and interpreted the patient data. ASHY and BN were two major contributors in writing the manuscript. MEs, FM, SM cooperated in referring patients. All authors read and approved the final manuscript and substantively revised it.

\section{Acknowledgements:}

The authors would like to thank the Clinical research development unit of Ghaem Hospital for their help in data analysis.

\section{References}

1. WHO General Director. WHO Director-General's opening remarks at the media briefing on COVID-19 - 5 March 20202020 [March 5, 2020]. Available from: https://www.who.int/director-general/speeches/detail/who-director-general-s-openingremarks-at-the-media-briefing-on-covid-19-5-march-2020. 
2. Dong M, Zheng J. Letter to the editor: Headline stress disorder caused by Netnews during the outbreak of COVID-19. Health expectations: an international journal of public participation in health care and health policy. 2020;23(2):259.

3. Huang Y, Zhao N. Generalized anxiety disorder, depressive symptoms and sleep quality during COVID-19 outbreak in China: a web-based cross-sectional survey. Psychiatry research. 2020;288:112954.

4. Azarpazhooh M, Amiri A, Morovatdar N, Steinwender S, Yassi N, Biller J, et al. Correlations between COVID-19 and burden of dementia: An ecological study and review of literature. Journal of the Neurological Sciences. 2020;416:117013-.

5. Yao H, Chen J-H, Xu Y-F. Patients with mental health disorders in the COVID-19 epidemic. 2020.

6. Qiu J, Shen B, Zhao M, Wang Z, Xie B, Xu Y. A nationwide survey of psychological distress among Chinese people in the COVID-19 epidemic: implications and policy recommendations. General psychiatry. 2020;33(2).

7. Larkin H. Navigating Attacks Against Health Care Workers in the COVID-19 Era. JAMA. 2021;325(18):1822-4.

8. Virtanen M, Ferrie JE, Gimeno D, Vahtera J, Elovainio M, Singh-Manoux A, et al. Long working hours and sleep disturbances: the Whitehall II prospective cohort study. Sleep. 2009 Jun;32(6):737-45. PubMed PMID: 19544749. Pubmed Central PMCID: PMC2690560. Epub 2009/06/24. eng.

9. Øyane NM, Pallesen S, Moen BE, Akerstedt T, Bjorvatn B. Associations between night work and anxiety, depression, insomnia, sleepiness and fatigue in a sample of Norwegian nurses. PloS one. 2013;8(8):e70228. PubMed PMID: 23950914. Pubmed Central PMCID: PMC3737208. Epub 2013/08/21. eng.

10. Kim M-S, Kim T, Lee D, Yook J-H, Hong Y-C, Lee S-Y, et al. Mental disorders among workers in the healthcare industry: 2014 national health insurance data. Ann Occup Environ Med. 2018;30:31-. PubMed PMID: 29755753. eng.

11. Vafaei H, Roozmeh S, Hessami K, Kasraeian M, Asadi N, Faraji A, et al. Obstetrics Healthcare Providers' Mental Health and Quality of Life During COVID-19 Pandemic: Multicenter Study from Eight Cities in Iran. Psychol Res Behav Manag. 2020;13:563-71. PubMed PMID: 32765131. eng.

12. Boniol M, Mclsaac M, Xu L, Wuliji T, Diallo K, Campbell J. Gender equity in the health workforce: analysis of 104 countries. World Health Organization, 2019.

13. Belingheri M, Paladino ME, Riva MA. Risk exposure to coronavirus disease 2019 in pregnant healthcare workers. Journal of Occupational and Environmental Medicine. 2020.

14. Schwartz DA. An analysis of 38 pregnant women with COVID-19, their newborn infants, and maternal-fetal transmission of SARS-CoV-2: maternal coronavirus infections and pregnancy outcomes. Archives of pathology \& laboratory medicine. 2020;144(7):799-805.

15. Jicha C, Saxon D, Lofwall MR, Fanucchi LC. Substance use disorder assessment, diagnosis, and management for patients hospitalized with severe infections due to injection drug use. Journal of addiction medicine. 2019;13(1):69-74.

16. Goldberg DP, Hillier VF. A scaled version of the General Health Questionnaire. Psychological medicine. 1979;9(1):139-45.

17. Nazifi M, Mokarami HR, Akbaritabar A, Faraji Kujerdi M, Tabrizi R, Rahi A. Reliability, validity and factor structure of the persian translation of general health questionnire (ghq-28) in hospitals of kerman university of medical sciences. Journal of Fasa University of Medical Sciences. 2014;3(4):336-42.

18. Alipour A, Ghadami A, Alipour Z, Abdollahzadeh H. Preliminary validation of the Corona Disease Anxiety Scale (CDAS) in the Iranian sample. Quarterly Journal of Health Psychology. 2020;8(32):163-75.

19. Ng J, Sham A, Tang PL, Fung S. SARS: pregnant women's fears and perceptions. British Journal of Midwifery. 2004 Nov;12(11):698-702.

20. Sappenfield E, Jamieson DJ, Kourtis AP. Pregnancy and susceptibility to infectious diseases. Infectious diseases in obstetrics and gynecology. 2013;2013.

21. Saccone G, Florio A, Aiello F, Venturella R, De Angelis MC, Locci M, et al. Psychological impact of coronavirus disease 2019 in pregnant women. American Journal of Obstetrics \& Gynecology. 2020;223(2):293-5.

22. Zimmermann P, Curtis N. COVID-19 in children, pregnancy and neonates: a review of epidemiologic and clinical features. The Pediatric infectious disease journal. 2020;39(6):469.

23. Presbyterian NY. New York Presbyterian (2020) General Visitation Guidelines 2020 [April 27, 2020]. Available from: https://www.nyp.org/coronavirus-information/coronavirus-visitor-policy-change.

Page $10 / 11$ 
24. Caron C, Van Syckle K. Some Pregnant Women in New York City Will Have to Deliver Babies Alone: The New York Times; 2020 [24 March, 2020]. Available from: https://www.nytimes.com/2020/03/24/parenting/coronavirus-labor-birth.html.

25. Brooks SK, Webster RK, Smith LE, Woodland L, Wessely S, Greenberg N, et al. The psychological impact of quarantine and how to reduce it: rapid review of the evidence. Lancet (London, England). 2020 Mar 14;395(10227):912-20. PubMed PMID: 32112714. Pubmed Central PMCID: PMC7158942. Epub 2020/03/01. eng.

26. Michels G, Ochmann U, Cranen R. Möglichkeiten der Beschäftigung von schwangeren Mitarbeiterinnen im Gesundheitssystem in Zusammenhang mit SARS-CoV-2. Medizinische Klinik - Intensivmedizin und Notfallmedizin. 2020 2020/09/01;115(6):486-7.

27. Magnavita N, Bonzini M, Foddis R, Debarbieri N, Del Bufalo P, Filon FL, et al. Protecting Pregnant Healthcare Workers. Journal of Occupational and Environmental Medicine. 2021;63(2).

28. Blandenier E, Habibi Z, Kousi T, Sestito P, Flahault A, Rozanova L. Initial COVID-19 outbreak: an epidemiological and socioeconomic case review of Iran. International Journal of Environmental Research and Public Health. 2020;17(24):9593.

29. Muller L. Pregnant nurse caring for COVID-19 patients: sometimes "I left work just bawling": Iowa Center for Public Affairs Journalism; 2021 [March 18, 2021]. Available from: https://www.iowawatch.org/2021/03/18/pregnant-nurse-caring-forcovid-19-patients-sometimes-i-left-work-just-bawling/.

30. Kahyaoglu Sut H, Kucukkaya B. Anxiety, depression, and related factors in pregnant women during the COVID-19 pandemic in Turkey: A web-based cross-sectional study. Perspect Psychiatr Care. 2021;57(2):860-8. PubMed PMID: 32989798. Epub 09/28. eng.

31. Liu X, Shao L, Zhang R, Wei Y, Li J, Wang C, et al. Perceived social support and its impact on psychological status and quality of life of medical staffs after outbreak of SARS-CoV-2 pneumonia: a cross-sectional study. Available at SSRN 3541127. 2020.

32. Tan BY, Chew NW, Lee GK, Jing M, Goh Y, Yeo LL, et al. Psychological impact of the COVID-19 pandemic on health care workers in Singapore. Annals of internal medicine. 2020;173(4):317-20.

33. Xiao H, Zhang Y, Kong D, Li S, Yang N. The effects of social support on sleep quality of medical staff treating patients with coronavirus disease 2019 (COVID-19) in January and February 2020 in China. Medical science monitor: international medical journal of experimental and clinical research. 2020;26:e923549-1. 